\title{
Policy for enhancing Pasifika learner achievement in New Zealand: Supports and challenges
}

Robin Averill

Victoria University of Wellington - Nova Zelândia

Fuapepe Rimoni Victoria University of Wellington - Nova Zelândia

\section{Resumo}

Os valores entendidos como fundamentalmente importantes em todos os grupos do Pacífico são centrais para as políticas educacionais da Nova Zelândia focadas na melhoria da aprendizagem escolar dos alunos Pasifika. Para explorar as percepções dos professores sobre três desses valores (respeito, serviço, liderança), foram recolhidos e analisados dados através de entrevistas com professores do ensino primário e secundário e da observação de aulas. Os resultados indicam que a implementação de políticas é desafiada pela falta de compreensão profunda, entre muitos professores, sobre os valores Pasifika. As implicações do estudo destacam que para melhorar as oportunidades de sucesso para os alunos Pasifika e facilitar a implementação de políticas são necessários o desenvolvimento profissional extenso e o recrutamento urgente de professores e líderes escolares com forte conhecimento das comunidades Pasifika.

Palavras-chave: Valores. Prática culturalmente sustentável. Implementação de políticas de educação. Educação Pasifika. Percepções de professores.

\section{Abstract}

Values understood to be fundamentally important across Pacific groups are central to New Zealand education policy focussed on enhancing school learning of Pasifika students. To explore teacher perceptions of three of these values (respect, service, leadership), interviews with primary and secondary teachers were collected and analysed and their lessons observed. Findings indicate policy implementation is challenged by a lack of deep understanding of Pasifika values amongst many teachers. Implications include that extensive professional development and urgent recruitment of teachers and school leaders with strong knowledge of Pasifika communities are needed to improve achievement opportunities for Pasifika learners and facilitate policy implementation.

Keywords: values. culturally sustaining practice. education policy implementation. 
Pasifika education. teacher perceptions.

Historical and continued disparity in educational achievement between students of different ethnic groups is problematic in many countries. Particular difficulties and responsibilities exist for governments and education sector groups in many contexts internationally in relation to ensuring educational settings maximise the potential of Indigenous learners and learners of many immigrant and minority groups (Chu, Glasgow, Rimoni, Hodis, \& Meyer, 2013). Research contributes to our understanding of culturally relevant, responsive, and sustaining practices (e.g., Gay, 2010; LadsonBillings, 1995; Paris, 2012) and asset-based approaches (CeledDn-Pattichis et al., 2018; Reynolds, 2018); all intended to enhance school engagement, participation, comfort, and academic achievement of marginalised student groups. Such research is used to inform policy development in many contexts including New Zealand. Education policy is often intended to be a driver of change, but equity-based policy can be difficult to implement, particularly when the ethnic demographics of the teaching population are poorly matched with the school learner population (e.g., Hynds et al., 2015).

The term 'Pasifika' was coined by the Ministry of Education to describe a diverse group encompassing all living in New Zealand who: "continue to have family and cultural connections to Pacific Island nations" (Ministry of Education, 2018, p. 5). Pasifika peoples have come to New Zealand from many Pacific Island countries, including the Cook Islands, Fiji, Niue, Samoa, Tokelau, Tonga, and Tuvalu, each country with their own languages and traditions. Further diversity amongst Pasifika groups exists, for example, in relation to how long families have been living in New Zealand, with many families having lived in the country for several generations and others having arrived much more recently. Pasifika cultures are dynamic and evolving (Anae, 2001; Coxon \& Wendt Samu, 2010; Hunkin-Tuiletufuga, 2001; Ministry of Education, 2018). While we acknowledge debate about the suitability of the term 'Pasifika' for encompassing all of these people (e.g., Samu, 2006), we use the term in this article as it is consistently used across the New Zealand policy documents being considered. Beliefs about New Zealand offering favourable educational opportunities that can contribute to realising their strong aspirations for their children are part of many Pasifika immigrants' rationales for coming to New Zealand (Fletcher, Parkhill, Fa'afoi, \& Taleni, 2006; Ministry of Education, 2018). Particularly for younger Pasifika people, confidence and competence with heritage languages and customs varies. Indigenous Māori constitute currently approximately $24 \%$ of the school age population, with Pasifika students roughly 10\% (Education Review Office, n.d.). Pasifika are however the fastest growing ethnic group in New Zealand, with one in five New Zealand learners expected to be of Pasifika heritage by 2050 (Ministry of Education, 2018; Statistics New Zealand, 2013).

There are relatively few New Zealand teachers with either Māori or Pacific heritage, approximately $11 \%$ and $3 \%$ respectively, with particularly low numbers of these 
teachers at the secondary school level (Education Counts, 2019). Given current teacher shortages leading to bringing in qualified teachers from overseas, there are increasing numbers of teachers who have very little New Zealand experience at all, let alone experience of Māori or Pasifika learners and communities. The main language of instruction in New Zealand schools is English, with limited use in schools of any Pasifika languages. Apart from some senior secondary school language instruction classes for national school qualifications (e.g., Samoan language), the main opportunity to experience Pasifika languages and cultures in New Zealand schools is through participation in voluntary cultural performance clubs (e.g., Fairbairn-Dunlop, 2010).

\section{The policy context}

While New Zealand is founded on a treaty agreement between Māori as the original people of New Zealand and the British crown with guiding principles of protection, participation, and partnership to safeguard Māori knowledge and interests, there is no equivalent arrangement ensuring equitable legal responsiveness to New Zealand's Pasifika peoples. New Zealand teachers are expected to demonstrate strong commitment to Māori learners and the treaty partnership, for example, by recognising "the unique status" of Māori in New Zealand and developing their personal understanding and use of the Māori language and custom (Education Council, 2017, p. 18). Support materials are provided to teachers to describe cultural competencies in relation to teaching Māori learners and to assist in associated development of teacher practice (Ministry of Education, 2011). However, many teachers lack confidence in their knowledge and understanding of the Māori world and in their ability to make a positive difference for Māori learners (Hynds, et al., 2015).

Despite Pasifika students currently comprising around 10\% of New Zealand school age learners, Pasifika academic achievement has tended to lag behind non-Pasifika students over time, often also behind that of Māori learners (e.g., Caygill, Hanlar, \& Singh, 2016; New Zealand Qualifications Authority, 2017). In response, the New Zealand government is prioritising system-wide development in order to improve the academic achievement of Pasifika learners. The 'Pasifika Education Plan' (Ministry of Education, 2013) lays out key government strategies for enhancing educational practice in relation to responsiveness to Pasifika learners and their families. Tapasā (Ministry of Education, 2018), a recent policy implementation publication, is intended primarily to: "support non-Pasifika leaders, teachers, and [governance] boards to engage with Pacific learners in culturally responsive ways" (p. 1) towards building: "Pasifika cultural competencies across the education workforce" (p. 3). Tapasā outlines a 'Pasifika Success Compass' (p. 4) towards enhancing school engagement, participation, and achievement of Pasifika through improving school and teacher practices. Central to the 'Pasifika Education Plan' (Ministry of Education, 2013) and the Tapasā Compass (Ministry of Education, 2018) are Pasifika learners, parents, families, and communities, and nine values fundamentally important across these groups: respect, service, leadership, family, reciprocal relationships, inclusion, 
belonging, spirituality, and love. These values are stated using English, as are the policy and policy implementation documents themselves. There is, therefore, strong potential for those with little or no Pasifika cultural knowledge and experience to interpret the values using only their own cultural lenses and worldviews, and hence to underestimate or misinterpret the depth and scope of their meanings to Pasifika people.

In the eyes of Pasifika learners and parents, effective teachers understand the values that are important to them (Ministry of Education, 2018). To help inform teaching of Pasifika learners, Tapasā (Ministry of Education, 2018) outlines three interwoven 'cultural competencies' using indicators of suitable practice for novice and experienced teachers and for educational leaders. The Tapasā indictors outline strategies to enhance teachers' culturally competence in relation to working with Pasifika learners, families, cultures, resources, and languages. Further, the indicators include that teachers must understand their own identity and culture and how these influence the way they think and act. Respect for learners and families, their values, worldviews, and cultural heritages is strongly reflected across all three competencies. Examples of cultural competency indicators explicitly linked to Pasifika values include that student teachers must understand: "the importance of retention and transmission of Pacific identities, languages and cultural values" (p. 10), and that beginning teachers should demonstrate: "understanding of Pacific values of reciprocity and respect in relationship building and communication" (p. 12). Other indicators embody the values more implicitly than these. For example, cultural competency indicators of experienced teacher practice include that they incorporate: "Pacific words, songs, activities, and artifacts to connect and engage with children and their parents" ( $p$. 13) and that educational leaders have: "strong relationships with Pacific communities and cultural leaders" (p. 13) and ensure their institution's achievement plan: "reflects the importance of identities, languages and cultures in Pacific learner health and educational success" (p. 11). To enact such expectations effectively requires practice that reflects and is consistent with the Pasifika values. Collectively, the indicators are likely to be daunting for many teachers in relation to the scope and depth of knowledge and understanding expected. The importance of teacher professional development to assist in the implementation of Tapasā is acknowledged, with short teacher workshops offered nationwide by the Teaching Council, New Zealand's professional organisation for teachers, soon after publication.

The national New Zealand curriculum (Ministry of Education, 2007) supports equitable teaching, having at its foundation principles of reflecting New Zealand's cultural diversity, community engagement, valuing: "the histories and traditions of all its people", and empowering: "all students to learn and achieve personal excellence, regardless of their individual circumstances" (p. 9). The curriculum emphasises that students will be encouraged to respect themselves and others and to value: "diversity, as found in our different cultures, languages, and heritages" (p. 10). School learning experiences are expected to help students learn about, express, and critically analyse their own values and, "with empathy", those of other groups and cultures (p. 10). 
However, prescribed curriculum content across learning areas does not explicitly reflect these ideals, or indeed, Pacific knowledge and skills. Much of the intended curriculum content is Eurocentric and Western focussed. That said, policy relating to ensuring Pasifika learner success is reflected strongly in the curriculum and other policy documents (Ministry of Education, 2007; 2013; 2018).

\section{The teaching context}

New Zealand educators need strong knowledge and understanding of their Pasifika students in order to teach them well (Allen \& Robertson, 2009; Chu, et al., 2013; Ferguson, Gorinski, Wendt Samu, \& Mara, 2008; Rimoni, 2016; Spiller, 2012). However, teachers may have stereotypical views of students of ethnicities other than their own and can be unaware of their students' beliefs, values, and perspectives (RubieDavies, Hattie, \& Hamilton, 2006). Understanding of the Pasifika values and how they can be incorporated into classroom and school practice is needed to help ensure educators can maximise Pasifika learner success (Hunter et al., 2016). However, deeply embedded Pasifika knowledge, values, and practices are: "rarely identified by schools as valuable in the classroom context" (Fa'ave, 2017, p. 51). Many New Zealand non-Pasifika teachers have little experience in Pasifika-based home, church, or other community settings. Even for those who believe in the importance of responding to Pasifika cultural worldviews in their work, it can be challenging to know how to develop deep culturally-linked understandings of the values. Teachers can develop their understanding of Pacific perspectives and cultural values by listening effectively to Pasifika learners and their families. Cultural learning is further reinforced by taking opportunities to develop their own and students' practice (Flavell, 2017; Reynolds, 2017), but such opportunities are not always available and are dependent on the willingness and skills of often very busy community members. Challenges also exist for Pasifika learners, whose home, school, and church lives can be disconnected experiences. Pasifika learners need to navigate and adjust to how they are expected to behave, interact, and learn within these separate contexts in order to achieve well (Education Review Office, 2012; Fletcher, Parkhill, Fa'afoi, \& O'Regan, 2009; Siope, 2011).

\section{The Pasifika values of respect, service, and leadership}

Having and demonstrating respect for students is a vital component of effective teacher-student relationships and interactions for Pasifika learners (Averill \& Clark, 2012; Hill \& Hawk, 2000; Spiller, 2012). Respectful relationships with Pasifika students help teachers to learn about these students' values and experiences (Hawk, Cowley, Hill, \& Sutherland, 2002; Samu, 2006; Tuioti, 2000) and maximise their learning and wellbeing (Averill, 2012). Such understandings help teachers develop a richer idea of each Pasifika child as a whole person (Samu, 2006). The interrelated values of service 
and leadership are also fundamentally important to Pasifika people (Fa'ave, 2017; Rimoni, 2016), as is the involvement of family in supporting students' learning (e.g., Tongati'o, Mitchell, Tuimauga, \& Kennedy, 2016). Recent studies have provided insights into the importance of teachers understanding the role of service and leadership in Pasifika learners' lives, and of demonstrating and nurturing service and leadership in their teaching (e.g., Allen \& Robertson, 2009). Many Pasifika students contribute to their family and community through holding substantial service and leadership roles outside school.

In summary, New Zealand education policy calls for system-wide enactment of specific Pasifika values towards enhancing the learning opportunities, experiences, and achievement of Pasifika learners. There is a growing proportion of Pasifika students in New Zealand schools, yet most New Zealand teachers are non-Pasifika. The values are expressed in English in policy documents, but their meanings are culturally embedded and nuanced, with specific meanings that may not be obvious to those without relevant cultural knowledge. Understanding teachers' perceptions of the Pasifika values is necessary to help inform policy implementation, to reduce disconnects between their school and out-of-school lives, and to ensure classrooms are suitable places for Pasifika learners to enjoy and make the most of their schoolbased education.

\section{The study}

In our initial teacher education programmes, the Pasifika values are used as a framework alongside Tapasā (Ministry of Education, 2018) to help student teachers learn how to enact national policy and work well with Pasifika learners and families. To inform our own practice with student teachers, most of whom are non-Pasifika, we explored primary and secondary teachers' perceptions and practice in relation to three values key to policy documents - respect, leadership, and service (Ministry of Education, 2013; 2018). We interviewed teachers to find out their perceptions of the values and how they believed they demonstrated them in their teaching and nurtured them in their students. We also observed their lessons to identify instances of enactment of these values in their teaching and interactions with students.

Data was collected from five Pasifika and nine non-Pasifika teachers across four English-medium schools (two primary and two secondary) with varying proportions of Pasifika students and teachers. Pasifika research guidelines (Anae, Coxon, Mara, Wendt-Samu, \& Finau, 2001) were used to inform the study design. For example, researchers were open to negotiation with participants, flexible, and willing to compromise rather than taking a rigid stance. Full ethical approval was gained. Study participants were all strong and committed teachers identified by both the researchers and a leader of their institution as making a positive difference for Pasifika learners. Semi-structured individual interviews enabled teachers' understandings to be explored. Interviews were carried out with one principal, six primary, and four 
secondary school teachers, and one teacher aide. One or two lessons taught by each teacher were observed by one of the researchers, with instances of the values being demonstrated and nurtured recorded on an observation schedule prepared by drawing key indicators of the values from literature. Data were gathered by both researchers together in one school and individually in the other schools. Analysis was carried out by the researchers independently reading and rereading the data and then together determining key themes. The study data was collected soon before the publication of Tapasā (Ministry of Education, 2018).

\section{Results}

Pasifika teachers explained that the importance of the values of respect, service, and leadership to the family and community is instilled in Pasifika children from a very young age. Pasifika children know respect for others is vital and that they are expected to carry out service and leadership responsibilities such as childminding and household chores. Showing respect and giving service involve Pasifika children assisting family, elders, community, and church with organising events, with service contributions becoming more specific and detailed with age. Pasifika teacher interview responses consistently showed deep ingrained holistic understandings about the values:

Leadership to me is like being a shepherd... it's all to do with nurturing and nourishing... trying all the strategies that bring everybody into the flock. (Pasifika Teacher)

Pasifika teacher responses show how the values play out in their actions, indicating the importance to them of the values for promoting wellbeing, and that they are an integral part of their teacher identity:

[Service is] making sure that everyone is in the right place both physically and mentally, that they're ready and they're happy - happy as in not troubled. (Pasifika teacher)

Service to me is coming to school knowing that God has put me in this place to share my gift with others, to serve others the best way I can, making the environment a safe learning environment, and for me to go the extra mile if someone needs extra help. [Learners] know I care about them and they care about me, so we serve each other. Service to me is really important. (Pasifika teacher)

Pasifika teachers told of leading their Pasifika learners by setting clear high expectations and building learners' confidence in their ability to do the work. One told us about telling their students about their own learning journey and success to inspire their students:

We're trying to build up these children as leaders. Like, sometimes if a kid says 'no, this book is too hard for me', I go, 'I don't think so', and I'll say, 'Do you know what? I believe in you. Do you believe in you?' and they sit there, and I say 'I'll give you two minutes. Do you 
want to read that book because I know it's your level' And they'll come 'I want to have a go.' Good. (Pasifika teacher)

I tell them I came from a poor family and look at me now! I say, 'You can get there. This is where you start. Say, yes, Ms X can do it, so can I!' (Pasifika teacher)

Pasifika teachers included learners' families in their responses:

Service is a three-way job, it's with the students, the parents, and the teachers... our community is needed and valuable. (Pasifika teacher)

In contrast, non-Pasifika responses tended to focus on their teaching role rather than a holistic view of interpersonal relationships with their students and families:

I like to think that the fact I care about their learning comes through in what I do, and that I'm willing to work with them if they're willing to buy into it. If students aren't willing to engage, I'm still going to be there trying to push them and encourage them... (Non-Pasifika Teacher)

While non-Pasifika teacher responses tended not to show deep knowledge of Pasifika worldviews or identities, they demonstrated clear respect for their students and what their students bring to their learning:

When I try and incorporate Pasifika culture in some of the [learning] tasks, I allow for students to offer ideas rather than expecting them to be standing and leading and saying, 'This is my culture, and this is what I do.' I open the door for opportunities... I can subtly say, 'Is this familiar to you? Do you know anything about this?' So, there's an opening, doesn't matter whether it gets filled or not, that's up to them, but where they can say, 'Yes, I know a lot about this, this is my culture and I'm happy to share.' (Non-Pasifika Teacher)

Differences in how the values are demonstrated by Pasifika and non-Pasifika are also indicated by feelings of Pasifika teachers who, particularly in schools with few other Pasifika teachers, can struggle to manage the role of being a de facto Pasifika community representative and champion for Pasifika learners in the school over and above their teaching role:

I'm now part of the [school] leadership. I think the most challenging thing for me, being Pasifika, is getting everyone to look at Pasifika learning through Pasifika eyes. I get tearful. Some teachers just don't get it. (Pasifika Teacher)

[Teachers say] 'They never do anything at home.' I have the courage to say, 'Stop, how can you know that?'... [Teachers] don't mean to be like that, it's just they think like a middle class European teacher working in a Pasifika world. Some try, some try. I feel there's a lot of education needs to go into teachers of Pasifika children. There are some passionate ones, but some will just look at a child and they've already judged that child... [saying things like] 'oh no, these children know they can't do that, it's no use telling them because their parents won't do that at home.' That infuriates me. (Pasifika teacher)

I wish our school had more [Pasifika] teachers because I think they understand where our kids are coming from. (Teacher aide) 
Non-Pasifika teachers identified that they and their colleagues have different understandings of the values than Pasifika do:

I'm having the Pasifika values modelled to me by other Pasifika teachers... as a Palagi, it's really good to be confronted with some of your own [understandings]... there's a lot of service, leadership being demonstrated and that is quite different [from my background], and I think that's really awesome. (Non-Pasifika Teacher)

You know people often think that Pasifika and Māori students come without having had experiences, but... we all need to recognise that they're just different experiences often from being Palagi, so it doesn't mean they have no experiences, and it's our job to find out what those experiences and strengths are. I hear this a lot, in other schools, "Well, they never come and tell us". Actually, it is our job to go and find out. (Non-Pasifika Teacher)

Analysis of the lesson observations showed many similarities between how the values were enacted and nurtured in the teaching of Pasifika and non-Pasifika teachers and some differences. Similarities included generic teaching strategies such as teachers reminding students of sharing responsibility for learning during groupwork, seeking agreement of students in relation to classroom decision-making rather than using teacher-directed practice, sharing clear expectations of work output, providing feedback and feedforward, and expecting students to help in classroom service roles. Most classroom observations did not expose practice strongly consistent with the experienced teacher or education leader cultural competency indicators (Ministry of Education, 2018).

Differences noticed between the teaching of Pasifika and non-Pasifika teachers included that Pasifika teachers were seen using examples from Pasifika community lives and heritage to help engage and explain concepts new to learners, revoicing student comments with corrected English pronunciation, and repeatedly emphasising their high expectations of students' achievement (e.g., "all of you are aiming to go to the university", "you are very good, very clever"). Familiarity with shared Pasifika teacher and Pasifika student understandings was evident, such as the teacher explaining examples in relation to church activities and when one Pasifika teacher encouraged their students to draw from their strengths and prior knowledge and experiences to help with their learning:

'Think in your own language first. Think in Samoan. Think in Syrian. Think [about the question] in your own culture. For example, in my culture, when you see someone having a shower, you think they are going somewhere, and you ask "where are you going?" and its really funny!' (Pasifika teacher)

The majority of the lesson content reflected European knowledge and skills across all lessons observed. However, in a social science lesson about climate change, one Pasifika teacher began the lesson with a video set in a Pacific Nation and expected students to ask their parents and grandparents for ideas towards their project on defining climate change, describing the impact of climate change on people or the 
environment, and suggesting how the community can help work to solve climate change-related problems.

Study limitations include that we interviewed and observed a small number of teachers and our results are therefore a small snapshot of practice. One researcher was Pasifika and the other non-Pasifika and although all care was taken to compare observation and interview data gathering foci, it is likely that pertinent data may have been missed or misinterpreted. However, taken overall, our findings provide evidence that Pasifika and non-Pasifika teachers differ in their understandings and enactments of the Pasifika values of respect, service, and leadership and hence are likely to bring different understandings to policy implementation.

\section{Discussion and conclusion}

The foundations of the national curriculum (Ministry of Education, 2007) provide useful groundwork for embracing cultural diversity, demonstrating high expectations of all learners, and helping students and teachers to understand their own and others' values. However, the fact that policy and policy support materials are needed to target and facilitate enhanced teaching of Pasifika learners in itself indicates that progress is needed towards ensuring all Pasifika children experience schooling that enables them to realise their academic potential while maximising their wellbeing. The complexity of the challenge for teachers and schools is enhanced by the diversity within and amongst Pasifika groups and the evolving nature of these cultures in New Zealand. The diversity across Pasifika adds multiple layers of challenge. Increasing numbers of Pasifika learners have more than one Pacific heritage nation. Language, capability with language, and engagement with heritage cultural activities and beliefs vary within and across those with heritage from different Pacific Nations. A further challenge to responsiveness to Pasifika learners and families is that many teachers are already grappling with developing their cultural competence in relation to Māori learners (Hynds et al., 2015; Ministry of Education, 2011). While there are some compatibilities between these and the competencies outlined in Tapasā (Ministry of Education, 2018), there are also distinct differences in values, languages, customs, expectations in relation to communication, and priorities between Māori and Pasifika peoples. If teachers and the education system overall were already bicultural in relation to being fully responsive to Māori learners and families, responsiveness by teachers and the education system to the values, languages, and knowledge from Pacific Island cultures may be achieved more swiftly and successfully.

Supports to policy implementation include Tapasā (Ministry of Education, 2018) itself, and professional development that will assist in helping teachers to enact the Tapasā cultural competencies. However, Tapasā (Ministry of Education, 2018) is both a resource and a challenge for teachers, as there is much involved for all in being able to demonstrate the indicators with integrity and confidence within a Eurocentric education system and society. In order to maximise the potential benefit for learners 
of increased understanding of the policy implications, professional development must be substantial and provide opportunities for teachers to experiment, reflect, discuss, and refine changes to their practice, ideally in partnership with learners and Pasifika school community members. However, teachers and schools are part of the communities within which they sit and changes in practice are often challenging to carry out, particularly when they require some communication with school communities and society more widely about the changes being implemented and their rationale.

Research into effective practice for Pasifika learners (e.g., Allen \& Robertson, 2009; Ferguson et al., 2008; Hill \& Hawk, 2000; Spiller, 2012) provides teachers and schools with further support for informing change to improve the opportunities of Pasifika learners to achieve to their potential. Many in New Zealand view cultural difference as an enriching and positive aspect of the country and many teachers care about ensuring equitable access to learning. However, our results help show the difference in knowledge and understanding of key aspects of education policy for improving learning for Pasifika learners between those with and those without Pasifika heritage. Traditional Eurocentric teacher and school practices are difficult to view critically through the lenses of worldviews other than one's own and hence policy implementation in relation to responsiveness to any marginalised groups may be slow and difficult.

Other challenges to policy implementation include that relatively few New Zealand teachers are Pasifika and there are increasing numbers of teachers who have relatively little experience in relation to teaching New Zealand Pasifika learners or the Pacific Nations they connect with. Many non-Pasifika teachers have limited understanding of the worldviews, languages, songs, stories, and other cultural aspects that Pasifika peoples hold dear. The policy documents and key values and competencies within them are expressed in English, potentially leading to interpretations linked with European worldviews and underestimation of the depth and scope of the meaning of the values to Pasifika.

Implications of our findings include that for the policy relating to enhancing learning opportunities of Pasifika students to be enacted, recruitment of teachers, specialised school-community communicators, and education leaders with deep understanding of Pasifika cultures are necessary and urgent. Also required is intensive culturally located and culturally sustaining professional development for current teachers and teacher educators and those new to New Zealand into ways to enact Pasifika cultural competencies and Pasifika values, knowledges, and understandings in their interactions and teaching. Specific selection criteria related to basic understanding of Pasifika cultures, languages, and values could be considered for those applying for initial teacher education programmes.

Implementation of the policy relating to enhancing Pasifika students' achievement and learning experiences (Ministry of Education, 2013; 2018) would benefit from 
enhanced understanding across New Zealand society of Pasifika values and experiences and a strong sense of collective societal responsibility for enabling and ensuring the implementation of equity-focussed policy. Our research is relevant internationally in relation to contexts where work is being done towards enhancing the learning of students of marginalised groups within the wider education system. Policy is only useful to those it is intended to assist to the extent to which it is supported and enlivened through collective understanding, intent, development, and action. Research such as ours is vital for identifying and describing context-specific supports for and challenges to policy implementation.

\section{References}

Allen, P., \& Robertson, J. (2009). "In order to teach you, I must know you." The Pasifika initiative: A professional development project for teachers. New Zealand Journal of Educational Studies, 44(2), 47.

Anae, M. (2001). The new Vikings of the sunrise: New Zealand-borns in the information age. In C. Macpherson, P. Spoonley, \& M. Anae (Eds.), Tangata o Te Moana Nui: The evolving identities of Pacific peoples in Aotearoa/ New Zealand (pp. 101-121). Palmerston North, New Zealand: Dunmore Press.

Anae, M., Coxon, E., Mara, D., Wendt-Samu, T., \& Finau, C. (2001). Pasifika education research guidelines. Wellington: Ministry of Education.

Averill, R., \& Clark, M. (2012). Respect in teaching and learning mathematics: Professionals who know, listen to and work with students. Set: Research Information for Teachers, 3, 50-57.

Caygill, R., Hanlar, V., \& Singh, S. (2016). TIMSS 2014/15: Mathematics Year 9: Trends over 20 years in TIMSS. Wellington, New Zealand: Ministry of Education. Retrieved from https://www.educationcounts.govt.nz/_data/assets/pdf_file/0018/180342/ TIMSS-2014-Maths-Y9-Report-FINAL.pdf

Celedón-Pattichis, S., Borden, L., Pape, S., Clements, D., Peters, S., Males, J. Chapman, O., \& Leonard, J. (2018). Asset-based approaches to equitable education research and practice. Journal for Research in Mathematics Education, 49(4), 373-389.

Chu, C., Glasgow, A., Rimoni, F., Hodis, M., \& Meyer, L. (2013). An analysis of recent Pasifika education research literature to inform improved outcomes for Pasifika learners (Report to the Ministry of Education). Wellington, New Zealand: Ministry of Education.

Coxon, E. \& Wendt Samu T., (2010). Pacific education research: New directions'. MAI Review, 1-4. 
Education Council. (2017). Our code our standards. Wellington, New Zealand: Author. Retrieved from: https://www.educationcouncil.org.nz/sites/default/files/Our\%20 Code\%200ur\%20Standards\%20web\%20booklet\%20FINAL.pdf

Education Counts. (2019). Teaching staff: Information on teaching staff in schools from 2004-2017. Wellington, New Zealand: Ministry of Education. Retrieved from: https://www.educationcounts.govt.nz/statistics/schooling/teaching_staff

Education Review Office. (2012). Improving education outcomes for Pacific learners. Wellington: Author.

Education Review Office. (n.d.). Ethnic diversity in New Zealand state schools. Wellington, New Zealand: Author. https://www.ero.govt.nz/footer-upper/news/ero-insi ghts-term-1/ethnic-diversity-in-new-zealand-state-schools/

Fa'avae, D. (2017). Family knowledge and practices useful in Tongan boys' education. Set: Research Information for Teachers, 2, 49-56.

Fairbairn-Dunlop, T. P. (2010). Pacific youth connecting through Poly. In C. Ward, J. Liu, T.P. Fairbairn-Dunlop, and A. Henderson (Eds.), Youth voices, youth choices: identity, integration and social cohesion in culturally diverse Aotearoa/New Zealand, (pp. 2029). Wellington, New Zealand: Victoria University of Wellington.

Ferguson, P.B., Gorinski, R., Wendt Samu, T. \& Mara, D. (2008). Literature Review on the experiences of Pacific learners in the classroom. Report for the Ministry of Education. Wellington, New Zealand: Ministry of Education.

Flavell, M. (2017). Listening to and learning from Pacific families: The art of building home-school relationships at secondary level to support achievement. Set: Research Information for Teachers, 2, 42-48.

Fletcher, J., Parkhill, F., Fa'afoi, A., \& O'Regan, B. (2009). Pasifika students', teachers' and parents' voice their perceptions of what provides supports and barriers to Pasifika students' achievement in literacy and learning. Teaching and Teacher Education, 25(1), 24-33.

Fletcher, J., Parkhill, F., Fa'afoi, A., \& Taleni, L. (2006). Pasifika learners' perceptions of barriers and support to reading and writing achievement in New Zealand schools. New Zealand Journal of Educational Studies, 41(2), 163-182.

Gay, G. (2010). Culturally responsive teaching: Theory, research and practice. (2nd ed.). New York: Teachers College Press.

Hawk, K., Cowley, E. T., Hill, J., \& Sutherland, S. (2002). The importance of the teacher/ 
student relationship for Māori and Pasifika students. Set: Research Information for Teachers, 3, 44-49.

Hill, J., \& Hawk, K. (2000). Making a difference in the classroom: Effective teaching practice in low decile, multicultural schools (AIMHI report to the Ministry of Educa tion). Wellington, New Zealand: Ministry of Education, Research Division.

Hunkin-Tuiletufuga, G. (2001). Pasefika languages and pasefika identities: Contemporary and future challenges. In C. Macpherson, P. Spoonley, \& M. Anae (Eds.), Tangata o te moana nui: The evolving identities of pacific peoples in Aotearoa/New Zealand (pp. 196-211). Palmerston North, New Zealand: Dunmore Press.

Hunter, J., Hunter, R., Bills, T., Cheung, I., Hannant, B., Kritesh, K., \& Lachaiya, R. (2016). Developing equity for Pasifika learners within a New Zealand context: Attending to culture and values. New Zealand Journal of Educational Studies, 51(2), 197-209.

Hynds, A., Averill, R., Penetito, W., Meyer, L., Hindle, R., \& Faircloth, S. (2015). Examining the impediments to indigenous strategy and approaches in mainstream secondary schools. International Journal of Leadership in Education, 19(5), 534-556. doi: 10.1080/13603124.2015.1051130.

Ladson-Billings, G. (1995). Toward a theory of culturally relevant pedagogy. American Educational Research Journal, 32, 465 - 491.

Ministry of Education. (2007). The New Zealand curriculum. Wellington, New Zealand: Learning Media.

Ministry of Education. (2011a). Tätaiako: Cultural competencies for teachers of Māori learners. Wellington, New Zealand: Author. Retrieved from http://www.teacherscou ncil.govt.nz/required/tataiako.stm

Ministry of Education. (2013). Pasifika education plan 2013-2017. Wellington: Minis try of Education.

Ministry of Education. (2018). Tapasā: Cultural competencies framework for teachers of Pacific learners. Ministry of Education, Wellington, New Zealand. Retrieved from http://www.elearning.tki.org.nz/News/Tapasa-Cultural-Competencies-Framework -for-Teachers-of-Pacific-Learners

New Zealand Qualifications Authority. (2017). Annual report on NCEA and New Zealand Scholarship data and statistics 2016. Wellington, New Zealand: Author.

Paris, D. (2012). Culturally sustaining pedagogy: A needed change in stance, termino logy, and practice. Educational Researcher, 41(3), 93-97. 
Reynolds, M. (2017). Video and va: Caring for relationality in Pasfika education. Set: Research Information for Teachers, 2, 34-41.

Reynolds, M. (2018). They always have my back: A strengths-based approach to understanding the value(s) of Pasifika brotherhoods in education in Aotearoa New Zealand. International Journal of Multicultural Education, 20(2), 1-23.

Rimoni, F. (2016). Tama Samoa stories: Experiences and perceptions of identity, belonging and future aspirations at secondary school. (Unpublished PhD thesis). Victoria University of Wellington, New Zealand.

Rubie-Davies, C. M., Hattie, J., \& Hamilton, R. (2006). Expecting the best for New Zealand students: Teacher expectations and academic success. British Journal of Educational Psychology, 76, 429-444.

Samu, T. W. (2006). The 'Pasifika Umbrella' and quality teaching: Understanding and responding to the diverse realities within. Waikato Journal of Education, 12, 35-49

Siope, A. (2011). The schooling experiences of Pasifika students. Set: Research Information for Teachers, 10(3), 11-15.

Spiller, L. (2012). “How can we teach them when they won't listen?”: How teacher beliefs about Pasifika values and Pasifika ways of learning affect student behaviour and achievement. Set: Research Information for Teachers, 3, 58-66.

Statistics New Zealand. (2013). 2013 Census Quick Stats about culture and iden tity. Retrieved from http://archive.stats.govt.nz/Census/2013-census/profile-and -summary-reports/quickstats-culture-identity/pacific-peoples.aspx/

Tongati'o, L., Mitchell, K., Tuimauga, F., \& Kennedy, S. (2016). Ngāue fakataha ki he ako 'a e fänau: Schools and parents and families working together to better unders tand and support Pasifika students' progress and achievement at school (Phase One). Wellington, New Zealand: Ministry of Education.

\section{Biografia}

\section{Robin Averill}

Victoria University of Wellington

Email: robin.averill@vuw.ac.nz ORCID https://orcid.org/0000-0002-8941-5565 


\section{Fuapepe Rimoni}

Victoria University of Wellington

Email: fuapepe.rimoni@vuw.ac.nz ORCID https://orcid.org/0000-0002-6318-2679 